\title{
CORONAVIRUS DISCOURSE OF UNCERTAINTY IN THE GUISE OF REASSURANCE: WE STAND TOGETHER ONLY WHEN WE DO NOT STAND APART
}

\author{
Željka Babić, Emir Muhić, Dijana Tica \\ Faculty of Philology, University of Banja Luka, Bosnia and Herzegovina
}

\begin{abstract}
The novel coronavirus communicative modalities are ever-emergent and infinitely adaptable systems of the new normal state of mind and play. By focusing on specificities found in the corpus extracted from three leading Bosnian and Herzegovinian $(B \& H)$ newspapers, the paper attempts to merge the predominant theoretical insight into a mixture of conceptual and critical theories of language. The focus of the paper is two-fold. The first one is targeted at testing the extracted theoretical posits on the linguistic corpora. The second aims at challenging the notions of togetherness and separateness in the B\&H society by mirroring them through the prism of Covid-19 newspaper reports. The results of the corpus analysis suggest that it is still possible to draw a line between the notions in accordance with the specific geographical regions from which the data are drawn.
\end{abstract}

Key words: coronavirus, discourse, uncertainty, threat, togetherness, apartness

\section{INTRODUCTION: THE BOSNIAN AND HERZEGOVINIAN BACKGROUND}

The specificity of the Bosnian and Herzegovinian $(\mathrm{B} \& \mathrm{H})$ society mirrors itself in almost all levels of life, for it is particular, and somewhat incomprehensible, the system always has to be looked at from three sides being: Bosnian/Bosniak, Croat and Serbian. The application to this so-called "three-headed monster" (a term which is usually used for describing a collective state presidency) type of approaching the issues is to be tested in terms of its applicability to the newspapers discourse in general. It is, therefore, necessary to give a short insight into some of the issues related to the researched points.

Bosnia and Herzegovina claims the legacy from the Social Federal Republic of Yugoslavia (known as ex-Yugoslavia) in which it was one of the six constituent republics. The newly-formed state consists of two entities, the Republic of Srpska (RS) and the Federation of Bosnia and Herzegovina $(\mathrm{FBiH})$, and a joint condominium, the Brčko District of Bosnia and Herzegovina (BD), which has its own government. The RS is an entity with a majority of Serbian population, with one central, entity government. The $\mathrm{FBiH}$ has a specific organisation, for it consists of ten cantons, in which there is either a predominant Bosnian or Croat population, with a central federal government which has a limited authority over its respective cantons. Such a motley administration is spread on

Submitted January $20^{\text {th }}, 2021$, accepted for publication February $23^{\text {rd }}, 2021$

Corresponding author: Željka Babić. Faculty of Philology, University of Banja Luka, Vojvode Petra Bojovića Blvd 1a, 78000 Banja Luka, Bosnia and Herzegovina |E-mail: zeljka.babic@flf.unibl.org 
other social, political, and educational levels, to name but a few. It is important to emphasise this fact, for it presents a basis for the establishment of a possible connection and traces it within the researched corpora. Namely, the separation is overt on multiple levels, even the name of the official language can be considered a stumbling stone. The official name of the language used in B\&H before 1992 was Serbo-Croatian or CroatoSerbian (srpskohrvatski ili hrvatskosrpski jezik). Nowadays, the official term one uses depends on their personal prevalence, thus, ending up with having Bosnian/Bosniak/Croatian/ Serbian, claiming that there exists only one polycentric/pluricentric language with different nominations or two/three different languages with their respective characteristics and specificities. The basis which lies beneath all these issues, the most important one, is that the language(s) used are understandable to all native speakers and that the previously mentioned issues in no way present any problem as far as comprehensibility is concerned, for their origin is not linguistically based. This, somewhat unique, three-fold position relates to almost all issues, including newspaper reports. Even though the underlined position of the media is overtly independent, the public opinion, as well as research, is that it is highly influenced by the part of the country it is published in and their owners as well.

\section{RESEARCH METHODOLOGY AND DISCUSSION}

In the pursuit to test the presence of the behaviour pattern related to in Theroux (2020) as a way of replicating the already set line of events, those being "the hoarding, the panicking, the fear, the blaming, the superstition, the selfishness, the surprising heroism, the fixation with the numbers of the reported dead, the boredom during quarantine", it seemed reasonable to test it on the newspaper corpora. Moreover, the overview of the plague literature research results asks for a possible comparison with the present-day situation with the Covid-19 pandemic and its representation in journalistic discourse. It is vital to emphasise the fact of the necessity of narrowing the scope of the researched issues, so the focus has been put on the terms related to Covid-19 in order to see whether there is any discrepancy in the results of the corpus analysis. The pandemic, (un)deservedly named infodemic ${ }^{1}$ by Cinelli et al. (2020), has offered itself as a resource to the researches almost instantaneously (Irwin 2020, Lewis 2020, Olsen, Pickard \& Westlund 2020).

For the purpose of this paper, the three daily newspapers published in Bosnia and Herzegovina have been chosen, namely Nezavisne novine (NN) (Serbian), Oslobođenje (O) (Bosnian) and Večernji list (VL) (Croatian). All three fulfilled the following criteria:

- they are daily newspapers published in the regional capitals (Banja Luka, Sarajevo, Mostar, respectively);

- they are considered representative of the governmental policies;

- they are all published in e-form which is searchable and downloadable in the Latin alphabet.

The corpus contains downloaded files from the date of the first recorded case of Covid19 in B\&H (Banja Luka, RS) $5^{\text {th }}$ March, 2020 until $22^{\text {nd }}$ May, 2020, which is the date of the cease of lockdown measures in the RS. The dates are chosen for they cover the first phase of the Covid-19 pandemic in B\&H in both entities, having in mind the fact that the

${ }^{1}$ The term is a blend coined by the journalist David Rothkopf and used in an article in The Washington Post on 11 May, 2003. For more information see https://www.merriam-webster.com/words-at-play/words-were-watchinginfodemic-meaning. 
lockdown in the Republic of Srpska started earlier and ended later than in the Federation of Bosnia and Herzegovina. The choice of the examples presented in the discussion shows the parallel nature of the research conducted. First seven examples present the presumed recurring notions hypothesised as possible signs of connection between the corpora. They also present the foundations for cognitive linguistic considerations. The other presented items were chosen as illustrations, for the format of the research allowed for mere establishment of existence or non-existence of the issues researched.

The analysis of the files has been done by the use of AntConc 3.5.8 (Macintosh OS X) 2019 tool, and the research apparatus used Content Analysis (Mayring 2014). The foundations for the research method were found in Clarke and Brown's (2013) six-step thematic analysis procedure, and the method used is mixed (Schwartz-Shea \& Yanow 2012, Yanow \& Schwartz-Shea 2006).

Starting from posit that the underlying methodological basis is to "conceptualize the process of assigning categories to text passages as a qualitative-interpretive act, following content-analytical rules" (Mayring 2014:10), content analysis offers itself as a "mixedmethod approach", in which quantitative and qualitative steps interchange paths. When discussing the issues concerning mixed-methods research as far as compatibility is concerned, Riazi (2016: 40-41) identifies for "the possibility of mixing the two research methodologies (quantitative and qualitative) in favour of more robust explanations of the phenomena". Hashemi (2012: 207) calls it "a useful tool for exploring complex systems investigating both the process and the outcomes". For the purpose of this paper, the term mixed-method has been understood in its broader sense, as stated in Schwartz-Shea \& Yanow (2012: 131), where the term encompasses "combinations of 'quantitative' and 'qualitative' methods in the same research project, at whatever phase". In the case of the research presented, it applies to the data collection process, the corpus analysis and the interpretation of results.

In order to systemise the newspaper data, the research used the Clarke and Brown's (2013) thematic analysis which, according to the author's presents a "distinctive method with a clearly outlined set of procedures in social sciences" (Brown \& Clarke 2013: 178), and it is usable on practically all kind of qualitative data. The articles were collected manually from the newspapers' websites, downloaded, and their titles inserted into a Numbers 10.2 file manually. The process of categorisations followed the six steps proposed by Clarke and Brown (2013): familiarisation with the data, coding, generating initial themes, reviewing themes, defining and naming themes, and writing up. This categorisation enabled later systematisation of data also. Namely, the discrepancy in the number of articles has its explanation in the pursuit of establishment of an evenness in the amount of words used in searches in total, i.e. the monthly items in the corpus used for comparison contain approximately similar number of lexical items, i.e. the word count for each month is approximately the same. Such a balance was be achieved by choosing the items belonging to a specific thematic group, after the data filtration and removal of overlapping articles. The researched articles contain between 50 and 500 words, and the approximate number of words per newspaper per months is the following: March 13,500 words, April 14,000 words and May 11,500 words. After the selection, the files were converted into machine readable plain text format (.txt), uploaded into the software and analysed.

However, it must be emphasised that these results ought to be understood as preliminary data, and the findings presented here only as illustrations of a much larger collection of corpora. It is important to mention that the hits were counted according to the occurrences in all cases in singular and plural in Serbian not only in the nominative, which is given as a matrix in the tables. 
The extracted examples have also been analysed through the prism of cognitive linguistic understanding of the terms separateness and togetherness, with the intention of seeing whether it is possible to obtain some data which will corroborate with the set hypothesis that it is possible to see clearly the difference in the newspapers reports in accordance with the part of B\&H they come from, even if the topic (in this case, Covid-19) is not locally politically challenging (Lakoff 1996, Musolff \& Zinken 2009, O’Halloran 2004, Oakley \& Hougaard 2008, van Dijk 2008).

\subsection{A Cross-Section of News Reports in B\&H}

The numbers of analysed newspaper articles connected with Covid-19, presenting all the articles $^{2}$ within the newspapers connected with the topic, are as follows:

Table 1 The number of articles analysed in the corpus

\begin{tabular}{|l|c|c|c|}
\hline & Nezavisne novine & Oslobođenje & Večernji list \\
\hline March & 124 & 64 & 65 \\
\hline April & 138 & 111 & 97 \\
\hline May & 111 & 92 & 66 \\
\hline Total & 373 & 267 & 228 \\
\hline
\end{tabular}

The situation in March is predominately reflected by a very concise presentation of the pandemic.

Table 2 Selected items from March 2020

\begin{tabular}{|l|r|r|r|}
\hline & Nezavisne novine & Oslobođenje & Večernji list \\
\hline zajedništvo [togetherness] & 1 & 0 & 66 \\
\hline odvojenost [apartness] & 1 & 0 & 0 \\
\hline nesigurnost [uncertainty] & 1 & 0 & 0 \\
\hline prijetnja [threat] & 6 & 9 & 32 \\
\hline porodica/obitelj [family] & $37 / 0$ & $178 / 0$ & $0 / 65$ \\
\hline nacija [nation] & 1 & 3 & 1 \\
\hline jedinstvo [unity & 2 & 1 & 0 \\
\hline pandemija virusa [virus pandemic] & 7 & 2 & 3 \\
\hline zaraza [infection, contagion] & 7 & 3 & 5 \\
\hline slučaj bolesti [cases of disease] & 1 & 1 & 0 \\
\hline uvezeni slučajevi [imported cases] & 3 & 142 & 27 \\
\hline $\begin{array}{l}\text { zabrana } \text { kretanja } \\
\text { [prohibition of movement/curfew] }\end{array}$ & $81 / 1$ & $12 / 277$ & $0 / 29$ \\
\hline policijski čas/sat [curfew] & 6312 & 959 & 236 \\
\hline korona [corona] & 2 & 4 & 56 \\
\hline kovid-19/covid-19 [Covid-19] & 67 & 4 & 3 \\
\hline klaster [cluster] & 43 & 136 & 5 \\
\hline $\begin{array}{l}\text { pozitivan na virus } \\
\text { [positive cases for the virus] }\end{array}$ & & & 0 \\
\hline
\end{tabular}

\footnotetext{
${ }^{2}$ All translations are made by authors.
} 
The first thing that draws the attention is the discrepancy in the number of occurrences of the lexical items infection/contagion and positive cases for the virus. There seems to be a negative correlation in the actual number of occurrences of the lexical items used and the actual geographical region where the virus has been registered, thus, Sarajevo seems as if it is warning that there actually exists a virus, while Banja Luka and Mostar, especially Banja Luka, just record the fact of the existence and give the plain numerical account. The first month of the pandemic also records the use of the lexeme corona rather than Covid19, with an interesting relation seen in the newspaper published in Croatian. A new word, cluster, is introduced into the vocabulary, which is definitely a specificity of this pandemic, for it somehow differentiates itself from the translational items, thus, relating only to Covid-19, and, in this case, the separate groups of isolated cases specific only to one particular town in $\mathrm{B} \& \mathrm{H}$, namely Banja Luka. The pinpointing of a cluster group, a cluster town/village, a cluster canton/entity from the beginning of the pandemic is a clear signal of the existence of a threat, which is somehow coming from the other side (whatever 'the other' refers to in each case). The overall feeling of the reports is quite positive, and the tendency recorded is that of giving numbers and pinpointing clusters. Even the beginning of segmental lockdown does not show any particular concern, just the need for alertness and care for others, especially the elderly and sick people. Another interesting point is the occurrence of the phrase (ključne) dvije sedmice/(ključna) dva tjedna [key two weeks] and the name of the RS Health Minister, Alen Šeranić. There is no record of the use of the word key as a premodifier in the corpus in March, and registered occurrences of two weeks, 12 in $N N, 2$ in $O$ and 6 in $V N$, just add some more flare to the feeling of positive expectations, hope and the feeling of near closure. The period is marked by a newly-introduced role model for behaviour, a person whose voice is listened to, a person who epitomises a positive outcome, a person whom all sides believe - the RS Health Minister. In March, there are 180 hits in $N N, 178$ in $O$ and 8 in $V N$ connected with his name. He is seen as the focal point around which people are gathered in their pursuit of finding a competent and trustworthy source. There is a scarce number of examples which point at the possibility of danger the virus carries. Moreover, the occurrences of the word opasnost [danger] in relation with Covid-19, $N N 3, O 3$, and $V N$ 2, show that the researched articles show a unanimous agreement in a favourable outcome. Still, with careful searching, one is able to find instances of the forthcoming times of insecurity. Namely, the search of the phrase radna mjesta [jobs] shows an interesting result. The $N N$ corpus displays 25 hits on the phrase modified with the verb poharati [to ravage], while $O$ has 1 accompanied by uticaj [influence] and $V N$ is accompanied by očuvati [to preserve].

The month of April breaks down into the chosen lexis is as follows: 
Table 3 Selected items from April 2020

\begin{tabular}{|l|r|r|r|}
\hline & Nezavisne novine & Oslobođenje & Večernji list \\
\hline zajedništvo [togetherness] & 161 & 25 & 45 \\
\hline odvojenost [apartness] & 3 & 2 & 1 \\
\hline nesigurnost [uncertainty] & 1 & 0 & 3 \\
\hline prijetnja [threat] & 72 & 22 & 2 \\
\hline porodica/obitelj [family] & $96 / 0$ & $496 / 0$ & $0 / 122$ \\
\hline nacija [nation] & 3 & 13 & 3 \\
\hline jedinstvo [unity & 1 & 1 & 1 \\
\hline korona [corona] & 9027 & 7018 & 1158 \\
\hline kovid-19/covid-19 [Covid-19] & $48 / 84$ & $0 / 826$ & $0 / 425$ \\
\hline klaster [cluster] & 13 & 280 & 66 \\
\hline pozitivan na virus [positive cases for the virus] & 1021 & 3 & 177 \\
\hline Republika Srpska [RS] & 698 & 829 & 94 \\
\hline Federacija BiH [FBiH] & 666 & 519 & 97 \\
\hline Brčko Distrikt $[\mathrm{BD}]$ & 300 & 240 & 5 \\
\hline karantin/karantena [quarantine] & $225 / 2$ & $569 / 130$ & $3 / 97$ \\
\hline žarište [focal point] & 21 & 129 & 23 \\
\hline radna mjesta [jobs] & 70 & 11 & 6 \\
\hline
\end{tabular}

Some of the researched lexemes have been changed because it was supposed that they would be in focus. The second month of the pandemic brought the total lockdown in $\mathrm{B} \& \mathrm{H}$, so it was viable to suppose it would be possible to find traces of doubt and insecurity. Strangely enough, the positive side offers itself in so much that the hope is represented through the catchphrase of the pandemic spread worldwide, the next two weeks/fourteen days, which are found in $O$ and $V N$. What is visible is the trend that will offer itself as a particular feature of this pandemic, and that is the avoidance of the use of the word positive. In the RS, it is visible that the reports are still done in the same way, but in the $\mathrm{FBiH}$, hedging starts to be the dominant way of reporting, so, e.g., instead of saying one tested positive for the virus there are instances of the use of phrases such as reported cases, recorded cases, contagious people, people with infection. The discrepancy in reporting about the pandemic does not exist in April, for even though the majority of cases are still recorded in the RS, especially in one city, Banja Luka, the existence of clusters within some of the FBiH cantons hovers its imminent cloak among all. So, even though the reports are spread between the RS and the $\mathrm{FBiH}$, what is evident is the necessity to come clean and acknowledge that the discrepancies within the numbers are due to the numbers of tested people and not the actual number of the recorded cases. Nevertheless, one finds these entries only in readers' comments, for the articles are still written in the form of barren statistical reports. Lastly, by following occurrences of the phrase radna mjesta [jobs] we see that the threat is definitely seen, for in $N N$ it collocates with the verbs očuvati [preserve] and sačuvati [keep], $O$ widens the collocates with the lexemes gašenje [putting out, closing] and ugrožen [jeopardised], while $V N$ also uses sačuvati [keep] and očuvanje [perseverance]. 
The month of May, understood as the month of hope and a possible end of the pandemic, brought an important event, namely the official opening of the country borders and lessening of restrictions within the country. Its importance as the transitory month between two big holidays is not seen in the newspaper reports, for they only emphasise the dropping numbers of cases which arose after the Catholic and Orthodox Easters, and give no marks to the possibility of any threat that the forthcoming Eid may bring.

Table 4 Selected items from May 2020

\begin{tabular}{|c|c|c|c|}
\hline & Nezavisne novine & Oslobođenje & Večernji list \\
\hline zajedništvo [togetherness] & 1 & 78 & 10 \\
\hline odvojenost [apartness] & 243 & 2 & 0 \\
\hline nesigurnost [uncertainty] & 4 & 0 & 1 \\
\hline prijetnja [threat] & 140 & 141 & 1 \\
\hline porodica/obitelj [family] & $96 / 0$ & $193 / 0$ & $0 / 234$ \\
\hline nacija [nation] & 2 & 26 & 0 \\
\hline jedinstvo [unity $]$ & 6 & 3 & 0 \\
\hline korona [corona] & 7028 & 7408 & 1126 \\
\hline kovid-19/covid-19 [Covid-19] & $19 / 34$ & $0 / 623$ & $0 / 62$ \\
\hline klaster $[$ cluster] & 7 & 18 & 2 \\
\hline novozaraženi [newly infected] & 97 & 385 & 43 \\
\hline respirator [respirator] & 198 & 92 & 11 \\
\hline kućna izolacija [home isolation] & 69 & 5 & 1 \\
\hline neodgovornost [irresponsibility] & 32 & 0 & 0 \\
\hline nenošenje (maske) [non-wearing (of a mask)] & 11 & 3 & 0 \\
\hline oporavljeno [recovered] & 40 & 169 & 8 \\
\hline radna mjesta [jobs] & 38 & 13 & 12 \\
\hline
\end{tabular}

What is evident is the emergence of the new dominant lexical item, respirator, as well as the increase in the use of a parallel term, Covid-19, in one paper. May is also the month in which the discrepancy in reporting is at its height. While $O$ sends positive vibrations in drawing the attention on the numbers of newly infected and recovered people, $N N$ is more preoccupied with the newly-coined negations (irresponsibility, non-wearing ${ }^{3}$ ) and the possible new sources of contagions (house isolation). The attention of the possible threat is now visibly pinpointed at people and they are solely seen as those who should bear all the responsibility (they should stay at home, wear face masks, be responsible). The moving of the attention from the society/community to an individual also means moving away from the collective responsibility and pointing fingers at the possibly "guilty" people. Very subtly, one enters the zone of uneasiness and uncertainty, which is being triggered by nocuous behaviour, which cannot be prevented by the authorities. Nor will they claim responsibility for the results of such a conduct of irresponsible individuals. The phrase jobs, surprisingly, still shows some inconsistencies. So, in $N N$, it is accompanied mostly by the predeterminer izgubljeno [lost], and only three other modifiers, viz. ugasila [extinguish], spasavanja [rescue], strah da se ne izgubi [fear of losing]; $O$ has instances of gubitak [loss], zatvaranje [closing], napusti [leave], spasimo [let's save]; VN mentions očuvanje

${ }^{3}$ It should be noted that the newspapers try to establish the existence of equal treatment of all of the citizens, so we have a report on " 61 persons being fined for not wearing masks" [NN, 12. 5. 2020.] and "a policeman being under investigation for not wearing the mask in public properly" [NN, 13. 5. 2020.]. 
[perseverance], zadržavanje [keeping], gubitak [loss], pogođenih [affected]. There is a surprising fact seen here. Namely, it seems that the pronounced end of the strict lockdown means the beginning of the times of uncertainty, which is felt more strongly. And it is that very uncertainty that brings the two/three sides together. The realisation that the future brings more insecurity and troubles than the actual pandemic, opens a door to the realisation that one has to turn to one's neighbour in times of need. A jeopardised individual means a jeopardised society as a whole, and the imminent threat of impossibility to predict the near future is just adding more need for closeness and bridging this artificial gap.

Let us finish this short overview by returning to one of only two joint holidays celebrated in the country, being Labour Day. It seems that only one side finds the connection with the present Covid-19 situation. Namely, NN offers 39 picks on Praznik rada [Labour Day] and 11 on Prvi maj [May Day], which are found as part of the Covid-19 related articles. Only one offers a collocation with an optimistic content, neko bolje sutra [some better tomorrow], while the other talks about a pandemic which stole [ukrala] the holiday away from them, and about people who now can only remember the beautiful days of Labour Day during Tito's age [pamte lijepe dane Praznika rada u Titovo doba]. The other two newspapers do not make any connection between the national holiday and the virus, apart from a short announcement in $O$ about the presence of the traditional reveilles by the brass bands. It seems that the pandemic failed in stealing holidays from the general public, for there seemed to be a lack of usual warnings and precautionary measures which filled newspaper columns when other holidays were observed.

Lastly, it is also noteworthy to add that the overwhelmingly rich selection of examples, the limited space for presentation and the very focus of establishment of the possible presence of the issues researched are the reasons for choosing the presented, selected data.

\subsection{Cognitive Linguistics Considerations}

The linguistic aspect used in this part of the paper is mainly conceptually framed using the salient building blocks from the ever-evolving construction site of cognitive linguistics. The analysis of discourse constructs in the media space of $\mathrm{B} \& \mathrm{H}$ in terms of coronavirus narratives is structured from the perspective of conceptual metaphor theory and cognitive models. It is equally grounded in one of the core values of cognitive linguistics making its way to the heart of the matter at hand. Namely, the idea of conceptualisation by means of which meaning is constructed and critically deconstructed so as to expose ideological systems originating in the idea-related mindset of a specific cognitive community and extract the needed meaning building blocks providing an example of the new coronavirus discourse. The tentative link between linguistics and medicine is not only a marriage of convenience. It is, to all intents and purposes, an uneasy and yet necessary relationship. It took some level of boldness to put together these interdisciplinary fields of scientific research.

The key ingredient in the attractive realm of the conceptually based system of analysis was advocated by George Lakoff ${ }^{4}$ who, unafraid of the difficulty of the task, took linguistics by storm and rewrote the disappearing image of the field and enriched it with revitalising incentive that opened up new horizons in the perception of the selected subject matter. In the case of the new coronavirus discourse as seen from a simultaneous standpoint, the conceptual analytical selection of approaches ${ }^{5}$ proves particularly useful and clearly revealing.

\footnotetext{
${ }^{4}$ https://georgelakoff.com/press/academic-biography/

${ }^{5}$ See Turner \& Fauconnier (2002).
} 
Through of the means of conceptual scenario deconstruction specifically designed with the intention to uncover singular characteristics of discourse construction of the $\mathrm{B} \& \mathrm{H}$ coronavirus narratives, advantage is given to the idealized cognitive model of unity through family modelled on Conceptual Metaphor Theory as elaborated by Lakoff in his well-known Women, Fire, and Dangerous Things published in 1987 and Metaphors We Live By that had been published seven years earlier. The previously mentioned volumes of his revolutionary writing furthered explained what transformed into standard procedure for decoding ideologically-coloured political tokens of discourse. The underlying principle states that the human capacity for generating and decoding meaning stems from the human-specific innate ability to perceive the surrounding material world and as a result store infinite information quantities into long-term memory bases in the neural system. The sequence explained in this way creates a routine pathway towards relatively stable and infinitely reusable suprastructures that enable access to general abstract semantic frames that in consequence make a two-pronged meaning possible with (de)coding mechanisms readily available.

The basic conceptual reference structure is called idealized cognitive model $^{6}$ because it uses the encyclopaedic knowledge accumulated in an individual's lifetime and quickly put to use if, or more precisely, when needed. Idealized cognitive models centre round the most noticeable and ever-present attributes of the category in question. Jungian concept of the collective unconscious ${ }^{7}$ neatly falls in with the entirety of cognitivist systems of linguistic mechanisms of analysis. To resort to Lakoff's example, a bird normally has a pair of two wings, the capacity for sustaining flight, and certain other bird-specific traits. Exemplars of a given category most adequately link with the defining coordinates if they have the highlighted markers. Should that be the case, they are classified as prototypes. In the above example, according to Lakoff, a sparrow is to be understood as a prototypical example of the bird class. All exemplars of a category do not deserve the status of prototypicality.

To explain potential deviations, the system of radiality was conceived. Radial categories state that exemplars or members are granted grades-based status ranks i.e. some exemplars are more central and therefore more prototypical, others deviate from the metaphorical centre more substantially and therefore they are perceived as less prototypical. The farther from the centre an exemplar lies, the less of a member it is. The cognitive machinery here presented demonstrates that human beings reason by means of analogy and conceptual comparison making human reasoning essentially experiential and the encyclopaedic knowledge hypothesis viable.

From the viewpoint of medical and the new coronavirus discourse, this is undeniably relevant keeping in mind what has previously been discussed. Lakoff claims that human thought first and foremost comes from conceptual comparisons similar to family-based communities. Nation or a conglomerate of nearby and connected units as a family generate conceptual scenarios if further supported with moral reasoning which does not rely on metaphoricity in itself, but rather experientiality which then conceptually connect the metaphorical construct of nation as a closely-knit family-like cognitive community and morality as one of the primary legitimising cornerstones of intertextuality. Intertexts strengthen the moral values forming the basis of the nation as a family scenario. In the new corona virus discourse, intertextuality links the primary text sources such as the literary treasure trove previously illustrated with modern-day discourse manoeuvres.

\footnotetext{
${ }^{6} \mathrm{http} / / / \mathrm{scodis} . c o m /$ for-students/glossary/idealized-cognitive-models/

${ }^{7}$ https://www.verywellmind.com/what-is-the-collective-unconscious-2671571
} 
Nation as a family is the of the utmost importance as conceptual lever of discourse production in this once-in-a-lifetime unprecedented discourse of crisis, medicine and linguistic mechanisms of reality-shaping.

To support the Nation as a Family or nation divided conceptual scenario, use was made of the articles, reports, opinion editorials and updates taken from the print media outlets for the purposes of shortness and clarity underpinning the conceptual highlights to be remarked upon in the conclusion.

Several underlying conceptual strategies in the generation of meaning in the new coronavirus discourse and the $\mathrm{B} \& \mathrm{H}$ cognitive community and its public arena are particularly important.

1. The easily detected usage of the unifying pronoun we as a hallmark of the inseparable nature of unified struggle.

2. The repetition of the sequences in our entity, the other entity and the authorities as another discursive mechanism (dis)unity.

3. The possessive determiner our is recurrent and equally indicative of the nation as a family conceptual scenario as well as a strategy of asserting the value system.

4. The combination of nations is seen as a family whose values revolve around the concept of being righteous and fair-handed. It is derived from the notion of nurturing parent.

5. In consequence, being a member of the conceptual family is both a privilege and a duty.

The Nation as a family conceptual scenario is a notion dependent on our perception of family as a phenomenon in need of care and nurturance so that is prospers into a fullyfledged form of existence. It is understood by means of human embodied experience transforming into the encyclopaedic knowledge repository. Child-rearing and nationbuilding are similar processes from a conceptual and analogically perception perspective. This conceptual parallel is an effective method of meaning detection, discourse analysis and ideological deconstruction asserting the value of conceptually-suffused cognitive linguistics in discourse studies and relevant at present, the novel coronavirus discourse.

Another point lends itself particularly useful for analysis and illustration. The conceptual metaphor of the Family of absence and Family of intermittent unity. This is especially noteworthy and in line with the previous qualitative cross-section extracting the lexical repository farmed in the infinite semantic ocean and put to frequent use.

The lexemes: pandemic, contagion, (newly detected) cases of disease, curfew, corona, Covid-19, cluster, positive cases, the Republic of Srpska, the Federation of Bosnia and Herzegovina, the Brčko District, quarantine, focal points, jobs, home and self-isolation, lack of responsibility, home-quarantine (stay/shelter in place order), use and the lack thereof of face masks/coverings and various other face shields. The aforementioned exemplars go to show how news-framers exploit a well-known stratagem of eliciting an emotional response: threat, fear, the unknown, the so-called invisible enemy, the extent of the new and cryptic threat, a new and mandatory modus vivendi (the new normal, the newness of everydayness), a community under siege and in need of protection. These mechanisms of conceptualisation by means of news framing are designed to mould and shape the susceptibly pliant mind of the reader into obedience for their own good. This is assertion is not partial to speculating the motivation driving this approach to news framing nor does it lay claim to a nefarious intent. The simple and patently observable paradigms are identified and illustratively set forth. It is also worth mentioning that this is merely a bitter taste of the novel corona discourse and by no means extensive and all-encompassing. This paper is the inception of a more detailed and ongoing effort to delineate the discursive strategies in the public sphere and will be the subject of further research endeavours. 


\section{CONCLUSION}

Unity and togetherness as the foundations of the B\&H society, at least those tested in the analysed corpora, seem still to be far-fetched. Namely, even though the upcoming twenty-fifth anniversary of the end of the conflict and the creation of the joint state would somehow presume the existence of one joint route, it is still visible that the invisible line of separation does not cease to exist, even in times of force majeure. This is quite interesting, for the great floods of 2014 united the country, so the same was expected here. Nevertheless, it seems that the fact that Covid-19 affected (and still is affecting) the whole population, and not just a part of it (which was the case during the 2014 flood crisis), contributed to the fact that the newspaper reports clearly differentiated in accordance with the part of the country they were published in. It is still unclear how long notions of separateness and togetherness are going to be visible in $\mathrm{B} \& \mathrm{H}$ society, but it is quite certain that they will present a challenge and an open call for researchers in the foreseeable future, or, at least, until one raises awareness of the fact that uniqueness or oneness should be considered just as an indivisible part of the whole.

\section{REFERENCES}

Braun, V., \& Clarke, V. (2013). Successful Qualitative Research: A Practical Guide for Beginners. SAGE.

Cinelli, M., Quattrociocchi, W., Galeazzi, A., Valensise, C. M., Brugnoli, E., Schmidt, A. L., Zola, P., Zollo, F., \& Scala, A. (2020, March 10). The COVID-19 Social media infodemic. ResearchGate. https://arxiv.org/pdf/2003.05004.pdf

Clarke, V. \& Braun, V. (2013). Teaching thematic analysis: Overcoming challenges and developing strategies for effective learning. Psychologist, 26(2), 120-123.

Irwin, R. E. (2020, July 13). Misinformation and de-contextualization: International media reporting on Sweden and COVID-19. Global Health, 16(62). https://doi.org/10.1186/ s12992-020-00588-X

Hashemi, M. R. (2012). Reflexions on mixing methods in applied linguistic research. Applied Linguistics 33(2), 206-212.

Lakoff, G., \& Johnson, M. (1980). Metaphors We Live By. University of Chicago Press.

Lakoff, G. (1987). Women, Fire, and Dangerous Things: What Categories Reveal About the Mind. University of Chicago Press.

Lakoff, G. (1996). Moral Politics: How Liberals and Conservatives Think. University of Chicago Press.

Lewis, S. C. (2020). The objects and objectives of journalism research during the coronavirus pandemic and beyond. Digital Journalism, 8(5), 681-689, https://doi.org/10.1080/ 21670811.2020.1773292

Mayring, P. (2014). Qualitative content analysis. Theoretical foundation, basic procedures and software solution. https://www.psychopen.eu/fileadmin/user_upload/books/mayring/ssoar2014-mayring-Qualitative_content_analysis_theoretical_foundation.pdf

Musolff, A., \& Zinken, J. (Eds.). (2009). Metaphor and Discourse. Palgrave Macmillan.

Oakley, T., \& Hougaard, A. (Eds.). (2008). Mental Spaces in Discourse and Interaction. John Benjamins.

O'Halloran, K. L. (Ed.). (2004). Multimodal Discourse Analysis: Systemic Functional Perspectives. Continuum. 
Olsen, R. K., Pickard, V., \& Westlund, O. (2020). Communal news work: COVID-19 calls for collective funding of journalism. Digital Journalism, 8(5), 673-680, https://doi.org/10. 1080/21670811.2020.1763186

Riazi, A. M. (2016). The Routledge Encyclopedia of Research Methods in Applied Linguistics: Quantitative, Qualitative, and Mixed-Methods Research. Routledge.

Schwartz-Shea, P., \& Yanov, D. (2012). Interpretative Research Design: Concepts and Processes. Routledge.

Smallman, S. (2015). Whom do you trust? Doubt and conspiracy theories in the 2009 influenza epidemic. Journal of International and Global Studies, 6 (2), 1-24.

Theroux, M. (2020, May 1). The end of coronavirus: What plague literature tells us about our future. The Guardian. https://www.theguardian.com/books/2020/may/01/the-endof-coronavirus-what-plague-literature-tells-us-about-our-future

Turner, M. \& G. Fauconnier. (2002). The Way We Think: Conceptual Blending and the Mind's Hidden Complexities. Basic Books.

van Dijk, T. A. (2008). Discourse and Power. Palgrave MacMillan

Yanow, D., \& Schwartz-Shea, P. (2006). Interpretation and Method: Empirical Research Methods and the Interpretive Turn. Routledge. 